УДК 341.231 .14

DOI https://doi.org/10.51989/NUL.2021.4.3

\title{
СУЧАСНЕ РОЗУМІННЯ ПРАВ ДИТИНИ
}

\section{Завгородня Юлія Степанівна,}

кандидат юридичних наук, доцент, доцент кафедри теорії та історії держави і права

Дніпропетровського державного університету внутрішніх справ

Актуальність теми дослідження зумовлюється необхідністю переосмислення концепції прав дитини, проблематика якої розв'язується переважно через призму теорії прав людини, яка була сформульована вітчизняним правознавством наприкінці XX століття. Натепер людські права інтерпретуються як обов'язкові вимоги до держави, що мають універсальний характер та існують незалежно від їх закріплення в тексті нормативно-правового акту.

Аналізуються права дитини й людські права через висвітлення таких їх ознак, як універсальність, фундаментальність, природний і невід'ємний характер, загальність, рівність, пріоритет над позитивним правом.

Характеризуючи універсальність як властивість людських прав і прав дитини, відзначається їх іманентна як універсальність, так і регіональний зміст, фактором чого є фундаментальні засади царини права: людська гідність, справедливість, зміст яких різний у межах різних соціальних утворень. Наявність різних міжнародних договорів, предметом регулювання яких $\epsilon$ саме права дитини, $\epsilon$ свідченням того, що досліджуваному явищу властивий міжнародний характер (як регіональний, так і універсальний), набуття ним універсальності. Наголошується, що Конвенція про права дитини була підписана майже всіма державами. Природа дитини не змінюється залежно від географічного місця ії перебування, а тому можливості дитини повинні бути забезпечені всіма державами.

Указується, що як те, що людські права забезпечують людині можливість відчуття себе людиною, так і права дитини є підгрунтям (основою) розвитку дитини, ії становлення як особистості. Права дитини зумовлюють сприйняття дитини не як об'єкта благодійності, а як суб'єкта права з його інтересами й цінностями. Права дитини невід'ємні, їх не можна скасувати, оскільки це суттєво вплине на розвиток і формування дитини як особистості. Безправна дитина перетворюється на об'єкт благодійності. Мало того, права дитини не можна скасувати саме через їх природний характер.

Резюмується, що аналіз ознак людських прав у контексті прав дитини дозволяє зробити висновок про спільність досліджуваних правових категорій. Права дитини значною мірою $\epsilon$ тими ж людськими правами (йдеться про права першого покоління). Інша частина прав дитини - соціальні, культурні, економічні - на відміну від людських прав мають ураховувати потреби дитини й уразливість носіїв цих прав.

Ключові слова: Конвенція про права дитини, людські права, права дитини, рівність, фундаментальність.

\section{Zavhorodnia Yuliia. Children's rights and human rights correlation}

The relevance of the research topic is stipulated by the necessity to rethink the children's rights concept, the problems of which are solved mainly through the prism of the human rights theory, which was formulated by domestic jurisprudence in the late twentieth century. Today, human rights are interpreted as mandatory requirements for the state, which are universal in nature and exist regardless of their enshrinement in the text of the legal act.

The rights of the child and human rights are analyzed through the coverage of their following features as universalism; fundamentality; natural and inalienable character, universality, equality, priority over positive law.

Characterizing universalism as a property of human rights and the rights of the child, it is noted that they possess both universality and regional content, the factor of which is the fundamental principles of law sphere: human dignity, justice, the content of which varies within different social formations. The existence of various international treaties, the subject of which is the rights of the child, is evidence that the phenomenon under study has an international character (both regional and universal), acquisition of universality by this phenomenon. It is noted that 
the Convention on the Rights of the Child has been signed by almost all states. The nature of the child does not change depending on the geographical location of the child, and therefore the child's capabilities must be provided by all states.

It is pointed out that just as human rights provide a person with the opportunity to feel a human being, so the rights of the child are the foundation (basis) of the child's development, his formation as a person. The rights of the child determine the perception of the child not as an object of charity, but as a subject of law with his interests and values. The rights of the child are inalienable and cannot be revoked, as this will significantly affect the development and formation of the child as a person. A disenfranchised child becomes an object of charity. Moreover, the rights of the child cannot be revoked precisely because of their natural character.

It is concluded that the human rights features' analysis in the context of children's rights allows us to conclude about the community of the legal categories under study. The rights of the child are largely the same human rights (first-generation rights). The rest of the rights of the child - social, cultural, economic in contrast to human rights should take into account the needs of the child and the vulnerability of the holders of these rights.

Key words: Convention on the Rights of the Child, human rights, children's rights, equality, fundamentalism.

Актуальність. Протягом останніх декількох років у вітчизняній правничій науці все більша увага приділяється проблематиці прав дитини. Водночас, iї розв'язання відбувається переважно через призму теорії прав людини, яка була сформульована вітчизняним правознавством наприкінці XX століття.

Однак, після проголошення курсу на євроінтеграцію, визнання юрисдикції Європейського суду з прав людини й необхідності виконання його рішень, виходячи із сучасних досягнень правничої науки у окресленій сфері теорія прав людини суттєво переосмислюється, зокрема через вертикальний вимір людських прав. На сьогодні людські права інтерпретуються як обов'язкові вимоги до держави, що мають універсальний характер та існують незалежно від їх закріплення у тексті нормативно-правового акту.

У такому контексті не можна не відмітити певну консервативність національної правової думки, що знайшла відбиття в назві другого розділу Конституції України, яка була прийнята в 1996 році (маємо на увазі зв'язок людських прав з обов'язками людини та пов'язування різнопорядкових явищ - людських прав та прав громадянина, що суперечить європейській концепції людських прав).

Наведене вказує на необхідність розв'язання низки завдань як передумови висвітлення дійної природи прав дитини, одними з яких $€$ з'ясування ознак і сутність прав дитини; визначення співвідношення прав дитини і людських прав. у дослідженні ми зосередимо увагу на останньому з них.

Наголосимо, що розв'язання вказаного завдання $\epsilon$ основою реалізації правового принципу рівності (оскільки права дитини, як вказує сама назва, пов'язуються з такою властивістю їх носія як неповнолітній вік, то в першу чергу йдеться про рівність незалежно від віку) та розбудови України як правової держави, вектор на розвиток якої визначений у ст. 1 Конституції України.

Відтак, проблематика співвідношення прав дитини і людських прав потребує розв'язання, що і визначає актуальність дослідження.

Аналіз останніх досліджень і публікацій. Як ми відзначили, права дитини стали предметом інтенції вітчизняних науковців протягом останніх років. Серед авторів робіт, присвячених окресленій проблематиці, слід згадати таких як В. Боняк, В. Глущенко, А. Дакал, С. Киренко, С. Коталейчук, М. Корнієнко, Н. Крестовська, Л. Кривачук, А. Кучук, М. Маніна, Н. Опольська, Л. Седюк, Т. Симоненко, Ю. Трестер, О. Фрицький та інші.

3 позитивної сторони слід відзначити спробу Н. Крестовської сформулювати принципи, що мають методологічне призначення для гносеології прав дитини: визнання автономії особистості дитини; визнання відмінностей між природними юридичними й реальними правами; визнання пріоритету інтересів дитини перед інтересами інших суб'єктів права; екзистенційно-гуманістичний підхід, що 
полягає в усвідомлення дитини як правової людини у процесі постійного розвитку та становлення правової особистості [1, с. 411-412].

Однак, не можна повною мірою погодитись із запропонованим підходом, зважаючи на таке. По-перше, не зрозуміло, що автор має на увазі під «природними юридичними правами» і «реальними правами», зважаючи на сучасне сприйняття людських прав як природних, які існують, як ми наголошували, незалежно від їх юридичного закріплення та реальний характер людських прав. Європейський суд з прав людини ще на початку другої половини XX століття вказав, що «Конвенція покликана гарантувати не права, які $\epsilon$ теоретичними чи ілюзорними, а права, які $\epsilon$ практичними та ефективними» [2]. У справі «Кандаракіс проти Греції» Європейський суд з прав людини в черговий раз відзначив, що людські права (зокрема, йшлося про право на доступ до суду) мають бути «практичним та ефективним», а не теоретичним чи ілюзорним Щоб право доступу було ефективним, особа повинна мати чітку, практичну можливість оскаржити акт, який $\epsilon$ втручанням у його права. Право на доступ до суду включає не тільки право порушувати провадження, але й право на «вирішення» спору судом [3]. По-друге, не зовсім правильно визначено пріоритет інтересів дитини, оскільки має йтися про сімейні відносини та окремі аспекти реалізації прав дитини, а не абсолютний пріоритет буд-яких інтересів, що явно суперечить загальноприйнятому принципу правової рівності. По-третє, ми не підтримуємо використання понять «правова людина», «правова особистість» як таких, що мають, на нашу думку, нульовий зміст.

Отже, бачимо, що дійсно існує необхідність у чіткому й послідовному процесі розуміння прав дитини.

Метою статті $\epsilon$ висвітлення співвідношення прав дитини та людських прав.

Виклад основного матеріалу. Для досягнення мети дослідження необхідно висвітлити окремі аспекти інтерпретації людських прав. У такому контексті варто згадати наукову роботу В. Боняк щодо термінологічної невизначеності поняття, що позначає можливості людини, необ- хідні для її існування та розвитку, в якому вченою «доведено, що терміни «права людини» (людські права), «основні права людини», «конституційні права», «основоположні права людини», «засадничі людські права» відмінні за своїм обсягом, а однойменні терміни несуть у собі різне смислове навантаження» [4, с. 18].

Водночас, не можна не відзначити й дослідження С. Головатого «Про людські права», у якому науковець обґрунтовує необхідність правильного розуміння відповідного явища та використання адекватних термінів, наголошуючи на необхідності використання терміну «людські права» замість терміну «права людини», оскільки останній спрямовує інтенцію вчених на «дарованості» прав суб'єкту, на наявність того, хто наділяє людину цими можливостями; натомість термін «людські права» вказує на природну належність прав людині, на іманентність людині прав [5]. Як видається, ця позиція С. Головатого $€$ цілком аргументованою і виваженою та сприяє уніфікації правничої термінології, а тому ми послуговуємось саме терміном «людські права».

Наступним кроком досягнення мети дослідження $\epsilon$ порівняння ознак людських прав та прав дитини. Водночас як властивості людських прав ми розглядаємо такі ознаки, виокремлені А. Кучуком: універсальність; фундаментальність; природний і невід'ємний характер, загальність, рівність, пріоритет над позитивним правом $[6$, c. 79].

1. Універсальність. Проводячи зіставлення досліджуваних категорій за цією ознакою слід вказати, що ми цілком підтримуємо позицію А. Кучука відносно властивості людським правам універсальності, однак, при цьому їм іманентний регіональний зміст [7, с. 234-262]. На цьому наголошував і відомий зарубіжний дослідник людських прав Д. Донеллі. На його думку концепція культурного релятивізму $\epsilon$ тим фактом, що важко заперечити, виходячи з того, що моральним нормам та соціальним інститутам властива культурна та історична мінливість. Однак, якщо людськими правами розуміти ті можливості, що належать особі тільки через те, що вона $\epsilon$ людиною, то вони повинні бути універсальними [8, с. 400-419]. 
Типовим прикладом, що підтверджує цю тезу $є$ приклад права на достатній життєвий рівень. Зрозуміло, що в межах, наприклад, України й Федеративної Республіки Німеччини «достатній рівень» буде різним, однак і в тій, і в іншій державі він буде.

Такий стан, на нашу думку, пов'язаний із природою права й людських прав. На сьогодні в межах західної традиції права їх підґрунтям визначаються людська гідність, справедливість , а їх зміст $€$ різним в межах різних соціальних утворень. Цілком слушно А. Кучук відзначає, що «однак у межах різних культур (цивілізацій) укладається різний зміст у вказані поняття. Черговий раз згадаємо відношення європейців і українців до умов відбування покарання у місцях позбавлення волі Норвегії А. Брейвіка. Тому гідність і справедливість навіть у межах Європи розуміється по-різному» [9, с. 128].

Щодо прав дитини, то в такому аспекті варто відзначити таке. Наявність різних міжнародних договорів, предметом регулювання яких $\epsilon$ саме права дитини, $\in$ свідченням того, що досліджуваному явищу властивий міжнародний характер (як регіональний, так і універсальний), набуття ним універсальності.

У означеному контексті варто згадати прийняту Генеральною Асамблеєю Організації Об'єднаних Націй 20 листопада 1989 року Конвенцію про права дитини. Цей міжнародний документ був підписаний майже всіма державами (не підписали Південний Судан, Сомалі, Сполучені Штати Америки).

Відтак, дійсно, можна стверджувати, що правам дитини властивий універсальний характер. Природа дитини не змінюється залежно від географічного місця ії перебування, а тому можливості дитини повинні бути забезпечені всіма державами. «Кожна дитина незалежно від стану здоров'я, національності, статі, соціального статусу мусить мати можливість зростати в сім'ї, отримувати адекватну освіту, не зазнавати дискримінації й брати участь у житті громади. I те, як почуваються наші діти, залежить не тільки від політики та заходів влади, а й від дій та ставлення оточуючих» $[10$, с. 3$]$.

2. Фундаментальність. Без прав людина перестає бути людиною, пере- творюючись на раба. Права - це те, що забезпечує особі належну життєдіяльність, дозволяє жити й розвиватись відповідно до власних уподобань, інтересів та цінностей. Водночас відзначимо, що, на нашу думку, важливим у означеному аспекті $\epsilon$ акцент саме на індивідуальному контексті. Маємо на увазі можливість обрання самою людиною того, як їй жити, чим займатися і т.д. Адже саме людина має визнаватися цінністю сама по собі, а не як член суспільства. Тому визначення в ст. 3 Конституції України людини як «основної соціальної цінності» $\epsilon$ певним атавізмом, спадком радянського колективного мислення. Не людина існує для соціуму, виконуючи його волю і через це визнається цінністю. Погляди людини можуть не співпадати з пропагандованими поглядами соціуму (поглядами більшості). Однак, саме в цьому і $\epsilon$ основа поступу суспільства, основа демократичного устрою та плюралізму. «А тому під час розв'язання державою будь-яких соціальних проблем, справ, питань саме людині, іiі існуванню й розвиткові повинен надаватися абсолютний, беззаперечний пріоритет. Права людини залишаються тим абсолютним, універсальним кордоном, переступати через який не може ніхто» [11] - наголошує В. Сокуренко.

Щодо прав дитини, то, на нашу думку, так як людські права забезпечують людині можливість відчуття себе людиною, бути людиною, так і права дитини $\epsilon$ підґрунтям (основою) розвитку дитини, ії становлення як особистості. Права дитини обумовлюють сприйняття дитини не як об'єкту благодійності, а як суб'єкта права 3 його інтересами та цінностями. Наголосимо, що ми не заперечуємо необхідність авторитету батьків, важливості сім'ї у розвитку дитини, лише зміщуємо акцент на ту складову частину, якій завжди відводилось другорядне значення. Відтак, йдеться переважно про позитивні дії (affirmative action), які дозволять не сприймати дитину суто як об'єкт впливу батьків та інших суб'єктів.

Відповідно до ч. 1 ст. 12 Конвенції про права дитини «Держави-учасниці забезпечують дитині, здатній сформулювати власні погляди, право вільно висловлювати ці погляди з усіх питань, що торкаються 
дитини, причому поглядам дитини приділяється належна увага згідно з ії віком і зрілістю» [12].

3. Природний характер, невід'ємність. Ця ознака характеризує людські права таким чином, що унеможливлює їх сприйняття як таких, що можуть надаватися людині державою чи іншим суб'єктом та, відповідно, ними ж і обмежуватися чи скасовуватися за їх волевиявленням. Права не надаються людині, вони належать їй від народження уже через те, що вона $\epsilon$ людиною. Відповідно, будь-який суб'єкт не може забрати права у людини, оскільки вони $\epsilon$ невід'ємною «частинкою» людини.

Така сама ситуація з правами дитини (принаймні з більшою їх частиною). Маємо на увазі, що в межах західної традиції права (включаючи і Сполучені Штати Америки) як людські права безумовно сприймаються так звані особисті та політичні права. Так, Сполучені Штати Америки не ратифікували Міжнародний пакт про економічні, соціальні та культурні права (американська правова доктрина не розглядає названі категорії як права; правами визнаються лише особисті та політичні права).

Права дитини $€$ невід'ємними, їх не можна скасувати, оскільки це суттєво вплине на розвиток і формування дитини як особистості. Безправна дитина перетворюється на об'єкт благодійності. Більш того, права дитини не можна скасувати саме через їх природний характер. Народження дитини зумовлює появу низки обов'язків у держави (а також і в батьків; у такому контексті можна вести мову і про горизонтальний вимір прав дитини).

4. Загальність, рівність. Права іманентні всім людям однаковою мірою, відповідно, правам властива загальність, а люди мають рівні права, незалежно від будь-яких ознак, наприклад, статі, кольору шкіри, раси та ін. Це положення $\epsilon$ засадничим для розбудови правової держави і для існування правопорядку загалом.

«Основу природного права й складає «рівність у праві» людини щодо будьчого - на життя, власну свободу, правову та соціальну рівність, власну самоідентич- ність та власне самоствердження тощо» [13, с. 24] - відзначають К. Вергелес, П. Куліш, Т. Школьнікова.

Виходячи з невід'ємності, фундаментальності прав дитини, не можна заперечувати і загальний та рівний їх характер. Єдина обмежувальна ознака - це вік. Про права дитини мова йде до досягнення людиною повноліття. Однак повноліття не $\epsilon$ тим фактором, що обумовлює припинення можливостей, що визнавались за дітьми. Зважаючи на зв'язок прав дитини з людськими правами, їх єдність (у більшості випадків, на чому ми наголошували вище), ці можливості реалізуються у царині людських прав.

5. Пріоритет над позитивним правом. Реалізація цього положення випливає з конституційного припису, закріпленого в ст.. 3: «Права й свободи людини та їх гарантії визначають зміст і спрямованість діяльності держави. Держава відповідає перед людиною за свою діяльність. Утвердження і забезпечення прав і свобод людини $\epsilon$ головним обов'язком держави» [14]. Більш того, варто нагадати, що для визначення правомірності обмеження людських прав застосовується трискладовий тест, у якому «відповідність закону» («відповідно до закону») $\epsilon$ лише однією складовою частиною, наявність якої не свідчить про правомірність вжитих обмежень.

Саме у цьому контексті варто сприймати і права дитини. Це природа будьяких прав: система права має побудована таким чином, щоб реалізувати права (маємо на увазі демократичну державу, оскільки у недемократичній державі людські права та інші права не визнаються та/ або ними нехтує публічна влада).

Висновки. Таким чином, як бачимо, проведений аналіз ознак людських прав у контексті прав дитини дозволяє зробити висновок про спільність досліджуваних правових категорій. Права дитини значною мірою $є$ тими ж людськими правами (йдеться про права першого покоління). Інша частина прав дитини - соціальні, культурні, економічні - на відміну від людських прав мають ураховувати потреби дитини та вразливість носіїв цих прав. 


\section{ЛITEPATУPA:}

1. Крестовська Н.М. Сучасне розуміння прав дитини. Форум права. 2011. № 3. С. 409-413.

2. Case of Airey v. Ireland (Application no. 6289/73). 9 October 1979. HUDOC : European Court of Human Rights. URL: http://hudoc.echr.coe.int/eng?i=001-57420.

3. Case of Kandarakis v. Greece (Applications no. 48345/12 and 2 others). 11 June 2020. HUDOC : European Court of Human Rights. URL: http://hudoc.echr.coe.int/eng?i=001-202754.

4. Боняк В.О. Термінологічна невизначеність категорії, що відображає можливості людини, необхідні для її існування та розвитку. Науковий вісник Дніпропетровського державного університету внутрішніх справ. 2018. Спеціальний випуск № 3 (94). С. 18-23

5. Головатий С.П. Про людські права. Лекції. Київ : Дух і літера, 2017. 760 с.

6. Кучук А.М. Теорія держави і права. Частина 1. Теорія держави : навчально-методичний посібник. Дніпро : Дніпроп. держ. ун-т внутр. справ, 2018. 111 с.

7. Кучук А.М. Основи теорії правового поліцентризму : монографія. Дніпро : Дніпроп. держ. ун-т внутр. справ; Ліра ЛТД, 2017. 312 с.

8. Donnelly J. Cultural Relativism and Universal Human Rights. Humanum Rights Quarterly.1984. № 6 (4). P. 400-419.

9. Кучук А.М. Універсальність / регіональність прав людини: правовий дискурс. Visegrad journal on human rights. 2016. № 1/1. С. 127-131.

10. 20-річчя Конвенції ООН про права дитини. Права дітей. 2009. С. 3.

11. Сокуренко В.В. Права людини як фундаментальна цінність. Національні та міжнародні механізми захисту прав людини. Харків, 2009. URL http://dspace.univd.edu.ua/xmlui/ bitstream/handle/123456789/2340/prava_Iyudini_yak_fundamental_na_cinnist.pdf?sequen$\mathrm{ce}=2$ \&isAllowed $=\mathrm{y}$.

12. Конвенція про права дитини : Міжнародний документ від 20 листопада 1989 року. База даних «Законодавство України». URL: https://zakon.rada.gov.ua/laws/show/995_021\#Text.

13. Вергелес К.М., Куліш П.Л., Школьнікова Т.Ю. Рівність у праві як онтологічна передумова самоідентифікації та самоствердження людини у світі. Рівність у праві: історична ретроспектива і сучасність. Львів : Ліга-Прес, 2019. С. 23-27.

14. Конституція України : Закон України від 28 червня 1996 р. № 254к/96-ВР / Верховна Рада України. URL: https://zakon.rada.gov.ua/laws/show/254\%D0\%BA/96-\%D0\%B2\%D1\%80. 